\title{
Pengaruh Senam Stroke Terhadap Kualitas Tidur Pada Penderita Hipertensi
}

\author{
Dewi Suryandari'), Irna Kartina ${ }^{2)}$ \\ ${ }^{1}$ Prodi S-1 Keperawatan, Universitas Kusuma Husada Surakarta \\ email: dewisuryandarikh@gmail.com \\ ${ }^{2}$ Prodi S-1 Keperawatan, Universitas Kusuma Husada Surakarta
}

\begin{abstract}
Abstrak. Stroke adalah cedera vaskuler pada otak atau adanya suatu cedera yang berat serta mendadak. Pencegahan adanya komplikasi lanjutan dari hipertensi yang mengarah pada stroke perlu dilakukan. Kesembuhan dan pencegahan pada pasien stroke dapat dilakukan melalui obat-obatan selama rumah sakit dan ditunjang dengan rehabilitasi atau latihan fisik. Salah satu latihan fisik adalah dengan melakukan senam. Senam stroke merupakan salah satu bentuk latihan fisioterapi yang disusun sedemikian rupa untuk dapat memberikan rangsangan kepada beberapa reseptor yang akan dibawa ke otak untuk diproses dan menghasilkan output berupa gerakan yang terkoordinasi. Metode penelitian ini adalah kuantitatif dengan Pre and Post Test Nonequivalent Control Group dengan sampel sebanyak 30 responden. Kualitas tidur telah diukur dengan PSQI. Hasil mean skor kualitas tidur pada kelompok intervensi sebesar 5.00 dan pada kelompok kontrol 8.71 dengan standar deviasi sebesar 1.309 pada kelompok intervensi dan 2.199 pada kelompok kontrol. Kesimpulan dari penelitian ini adalah senam stroke memiliki pengaruh yang signifikan $p$ value $<0.00$. terhadap kualitas tidur pada pasien dengan hipertensi.
\end{abstract}

Kata kunci: senam stoke, hipertensi, kualitas tidur

\section{The Effect of Stroke gymnastics toward Quality of Sleep in Patients with Hypertension}

Abstract. Stroke is a vascular injury that can happen in the brain suddenly or immediately after ther accumulation of tension or obstruction, it is also incleded as severe injury. One condition can lead stroke attack is hypertension, regarding this complication, prevention of further complication needs to be prepared. Healing and prevention in stroke patients can be done through drugs during the hospital and supported by rehabilitation or physical exercise. One of physical exercises is to do gymnastics. Stroke gyme is a kind of physiotherapy exercises that arranged in such a way as to be able to provide stimulation to several receptors that will be brought to the brain to be processed and produce output in the form of coordinated movements. This research method was quantitative with Pre and Post-Test Nonequivalent Control Group with sample 30 respondents, quality of sleep was measured by PSQI, Results showed that mean of PSQI score in the intervention group was 5.00 and in the control group 8.71 with a standard deviation of 1.309 in the intervention group and 2,199 in the control group. Conclusion of this study is Stroke gymnastics significantly(p value $<0.00)$ effected the quality of sleep in patients with hypertension .

Keywords: stroke exercise, hypertension, sleep quality 


\section{Pendahuluan}

Stroke merupakan penyebab kematian paling sering didunia pada tahun 2011 dengan jumlah 6,2 juta kematian (WHO, 2013). Stroke merupakan penyebab kematian dan kecacatan utama dihampir seluruh Rumah Sakit (RS) di Indonesia yaitu sebesar 15,4\% (Kemenkes RI, 2011). 80\% klien stroke mempunyai defisit neuromotor sehingga memberikan gejala kelumpuhan sebelah badan dengan tingkat kelemahan, kehilangan sensibilitas, kegagalan system koordinasi, peribahan pola jalan sampai terganggunya keseimbangan tubuh (Widianto, 2009). Pencegahan adanya komplikasi lanjutan dari hipertensi yang mengarah pada stroke perlu dilakukan. Kesembuhan dan pencegahan pada pasien stroke dapat dilakukan melalui obatobatan selama rumah sakit dan ditunjang dengan rehabilitasi atau latihan fisik. Salah satu latihan fisik adalah dengan melakukan senam.

Senam stroke merupakan salah satu bentuk latihan fisioterapi yang disusun sedemikian rupa untuk dapat memberikan rangsangan kepada beberapa reseptor yang akan dibawa ke otak untuk diproses dan menghasilkan output berupa gerakan yang terkoordinasi (Basmara, Gusty \& Julita, 2012). Latihan fisik selain bermanfaat untuk kebugaran tubuh, juga bermanfaat untuk menstabilkan fungsi sistem organ manusia (Soegiarto, 2004 dalam Basmara, Gusty \& Julita, 2012). Hasil penelitian Bassetti (2011), bahwa prevalensi gangguan sering terbangun sebesar 20 sampai $40 \%$ pada pasien yang terkena stroke. Pasien stroke bisa mengalami gangguan dan masalah tidur. Gangguan tidur ini dapat bermanifestasi dalam beberapa bentuk tergantung pada defisit neurologik spesifik yang ditimbulkan (Sekeon \& Kembuan, 2011). Obesitas, diabetes, penyakit jantung koroner dan hipertensi merupakan faktor resiko terjadinya hipertensi pada orang dewasa. Kondisi tidur yang singkat atau sebentar dapat menyebabkan gangguan metabolisme dan endokrin, yang dapat berkontribusi menyebabkan gangguan kardiovaskuler. Kualitas tidur adalah suatu keadaan tidur yang dijalani seorang individu menghasilkan kesegaran dan kebugaran saat terbangun. Kualitas tidur mencakup aspek kuantitatif dari tidur, seperti durasi tidur, latensi tidur serta aspek subjektif dari tidur (Cahyono, 2014).

\section{Metode}

Penelitian yang digunakan
adalah penelitian kuantitatif.
Rancangan penelitian yang
digunakan dalam penelitian ini
dengan menggunakan Pre and Post
Test Nonequivalent Control Group
adalah penelitian yang dilakukan
untuk membandingkan hasil
intervensi dengan reara
melibatkankelompok kontrol
disamping kelompok eksperimen,
tapi pemilihan kedua kelompok ini
tidak menggunakan teknik acak(
Nursalam, 2016).

Populasi dalam penelitian 
ini adalah semua lansia penderita hipertensi di Dusun Siwal sejumlah 29 orang. Teknik sampling dengan menggunakan purposive sampling yaitu teknik penentuan sampel dengan pertimbangan tertentu yang didasarkan pada kriteria inklusi (Sugiyono,2010).

Kriteria inklusi:

a. Bersedia menjadi responden

b. Berusia 55 sampai 70 tahun

c. Tidak mengalami gangguan mobilitas fisik ( lumpuh, atrofi, susah berjalan)

Kriteria eksklusi:

a. Pasien yang mengalami penurunan kondisi

b.Pasien yang menolak melanjutkan kegiatan

Pengumpulan data pada penelitian ini menggunakan kuesioner PSQI yang sudah baku. Kuesioner PSQI terdiri dari 7 komponen meliputi subjective sleep quality, sleep latency, sleep duration, habitual sleep efficiency, step disturbance, use of sleeping medication dan daytime disfunction.

Penelitian ini dimulai dengan mengurus perijinan dari Institusi Stikes Kusuma Husada Surakarta, bidan desa dan Bayan Dusun Siwal. Tahap selanjutnya adalah mempersiapkan kuesioner PSQI. Kuesioner yang digunakan dalam penelitian ini adalah closed ended questions yaitu kuesioner yang sudah tersedia jawabannya sehingga responden tinggal memilih (Nursalam 2011). Penelitian ini menggunakan kuesioner PSQI yang terdiri dari 7 komponen meliputi subjective sleep quality, sleep latency, sleep duration, habitual sleep efficiency, step disturbance, use of sleeping medication dan daytime disfunction. Tahap selanjutnya adalah pengambilan data primer dalam penelitian ini adalah data yang diambil dari responden penelitian yang diukur dengan mengisi kuesioner. Pada hari sabtu tanggal 12 Mei 2018 dilakukan pengukuran tekanan darah, menimbang berat badan dan pengisian kuesioner PSQI. Pada hari Senin dilakukan senam pertama, Rabu dilakukan senam kedua, dan hari Juamt dilakukan senam ketiga. Pada hari Sabtu tanggal 19 Mei dilakukan pengukuran PSQI post senam stroke. Tahap selanjutnya peneliti membuat laporan hasil penelitian.

$$
\text { Pengolahan data }
$$

dilakukan dengan menggunakan komputer melalui proses editing, coding, tabulating dan entry data. Hasil penelitian di analisa menggunakan uji Mann Whitney karena dilakukan pada data non parametrik dengan uji beda 2 mean.

\section{Hasil Penelitian \\ Penelitian ini mengambil hasil data berupa karakteristik dari responden yaitu lansia di dusun Siwal. Adapun hasilnya sebagai berikut :}


Tabel IV.1

Umur Lansia di Dusun Siwal

\begin{tabular}{cccc}
\hline No & Kategori Umur & $\begin{array}{r}\text { Frek } \\
\text { uensi }\end{array}$ & $\begin{array}{c}\text { Persentas } \\
\text { e (\%) }\end{array}$ \\
\hline 1. & lansia awal (60-74) & 29 & 100 \\
\hline 2. & lansia tua (75-90) & 0 & 0 \\
\hline \multicolumn{3}{c}{ Jumlah } & 100 \\
\hline \multicolumn{3}{c}{ Kecamatan Selokaton }
\end{tabular}

Berdasarkan distribusi umur lansia di Dusun Siwal Kecamatan Selokaton diketahui bahwa $100 \%$ responden dalam penelitian ini adalah berusia $60-70$ tahun.

Proses menua adalah suatu proses menghilangnya secara perlahan kemampuan jaringan dalam memperbaiki, mengganti diri, mempertahankan struktur dan fungsinya, sehingga tidak dapat bertahan terhadap infeksi dan memperbaiki kerusakan yang diderita. Umur adalah satuan waktu yang mengukur waktu keberadaan suatu benda atau makhluk, baik yang hidup maupun yang mati( Indra, 2013). Responden dalam penelitian ini berusia lebih dari 55 tahun yang mengikuti posyandu lansia di Dusun Siwal. Jumlah responden sebanyak 29 lansia. Berdasarkan distribusi umur lansia di Dusun Siwal Kecamatan Selokaton diketahui bahwa $100 \%$ responden dalam penelitian ini adalah berusia 60-70 tahun. Seiring bertambahnya usia seseorang, hampir setiap orang m,engalami adanya peningkatan tekanan darah. Usia 80 tahun, tekanan sistolik terus meningkat( Ayu, 2010).
Tabel IV.2

Jenis Kelamin Lansia di

Dusun Siwal Kecamatan

Selokaton

\begin{tabular}{llcc}
\hline No & $\begin{array}{c}\text { Jenis } \\
\text { Kelamin }\end{array}$ & Frekuensi & $\begin{array}{c}\text { Persentase } \\
(\mathbf{\%})\end{array}$ \\
\hline 1. & Laki-laki & $\mathbf{8}$ & 27,59 \\
2. & Perempuan & 21 & 72,41 \\
\hline & Jumlah & 29 & 100,0 \\
\hline
\end{tabular}

Berdasarkan distribusi jenis kelamin lansia di Dusun Siwal Kecamatan Selokaton diketahui bahwa 8 lansia $(27,59 \quad \%)$ mempunyai jenis kelamin laki-laki dan 21 lansia $(72,41 \%)$ mempunyai jenis kelamin perempuan, diketahui bahwa sebagian besar lansia di Dusun Siwal Kecamatan Selokaton berjenis kelamin perempuan.

Berdasarkan distribusi jenis kelamin lansia di Dusun Siwal Kecamatan Selokaton diketahui $72,41 \%$ berjenis kelamin perempuan. Menurut Sarwono (2007) dalam Ayu (2010), peran gender merupakan komponen peran sosial. Lingkungan serta faktor lainnya berperan serta dalam hal ini. Tekanan darah pada perempuan pada umumnya meningkat setelah mengalami menopause. Hipertensi dapat terjadi pada perempuan memasuki masa menopause. Perubahan hormonal dan biokimia yang terjadi di dalam tubuh setelah menopause adalah penyebab utama perubahan tekanan darah. Perubahan hormon tersebut membuat perempuan mengalami peningkatan sensitivitas terhadap garam dan penambahan berat badan. Kedua hal tersebut 
berpotensi memicu tekanan darah yang lebih tinggi dan dapat terjadi komplikasi berupa serangan stroke (Harmoni, 2007).

Tabel IV.3

Pendidikan Lansia di Dusun Siwal Kecamatan Selokaton

\begin{tabular}{cccc}
\hline No & Pendidikan & Frekuensi & $\begin{array}{c}\text { Persentase } \\
(\%)\end{array}$ \\
\hline 1. & Sekolah Dasar & 9 & 31,03 \\
2. & Tidak sekolah & 21 & 68,97 \\
\hline & Jumlah & 29 & 100,0 \\
\hline
\end{tabular}

Berdasarkan distribusi

pendidikan lansia di Dusun Siwal Kecamatan Selokaton diketahui bahwa 9 lansia $(31,03 \%)$ mempunyai pendidikan dasar dan 21 lansia $(68,97 \%)$ tidak bersekolah, sehingga dapat diketahui bahwa sebagian besar lansia di Dusun Siwal Kecamatan Selokaton latar belakang pendidikan adalah tidak bersekolah.

Pendidikan adalah usaha sadar dan terencana untuk mewujudkan suasana belajar dan proses pembelajaran untuk peserta didik agar secara aktif mengembangkan potensi dirinya untuk memiliki kekuatan spiritual keagamaan, pengendalian diri, kepribadian, kecerdasan, akhlak mulia, serta keterampilan yang diperlukan dirinya dan masyarakat (Zakky, 2018). Berdasarkan UU no 20 tahun 2003, pendidikan adalah usaha sadar dan terencana untuk mewujudkan proses pembelajaran agar peserta didiksecara aktif mengembangkan potensi dirinya untuk memiliki kekuatan spiritual, pengendalian diri, kepribadian, kecerdasan, akhlak mulia, serta keterampilan yang diperlukan dirinya, bangsa dan negara.

Berdasarkan tabel dapat kita lihat bahwa pendidikan lansia di Dusun Siwal Kecamatan Selokaton diketahui bahwa $68,97 \%$ tidak bersekolah. Latar belakang pendidikan seseorang, merupakan dasar seorang individu untuk berfikir dan bersikap terhadap sesuatu. Hal ini sejalan dengan penelitian Nurwidayanti \& Wahyuni( 2013), hasil penelitian menunjukkan bahwa tingkat pendidikan berpengaruh secara signifikan terhadap kejadian hipertensi.

Tabel IV.4

Analisa Bivariat kualitas tidur sebelum senam stroke

\begin{tabular}{lccc}
\hline No & $\begin{array}{c}\text { PSQI } \\
\text { intervensi }\end{array}$ & $\begin{array}{c}\text { PSQI } \\
\text { kontrol }\end{array}$ \\
\hline N & Valid & 15 & 14 \\
& Missing & 0 & 1 \\
\hline Mean & 9.40 & 9.29 \\
\hline Std.Deviation & 2.165 & 1.309 \\
\hline
\end{tabular}

Berdasarkan tabel di atas diperoleh bahwa variabel kualitas tidur sebelum senam stroke memiliki hasil mean pada kelompok intervensi sebesar 9.40 dan pada kelompok kontrol 9.29.

Tabel IV.5

Analisa Bivariat kualitas tidur setelah senam stroke

\begin{tabular}{llcc}
\hline No & & $\begin{array}{c}\text { PSQI } \\
\text { intervensi }\end{array}$ & $\begin{array}{c}\text { PSQI } \\
\text { kontrol }\end{array}$ \\
\hline N & Valid & 15 & 14 \\
& Missing & 0 & 1 \\
\hline Mean & 5.00 & 8.71 \\
\hline
\end{tabular}




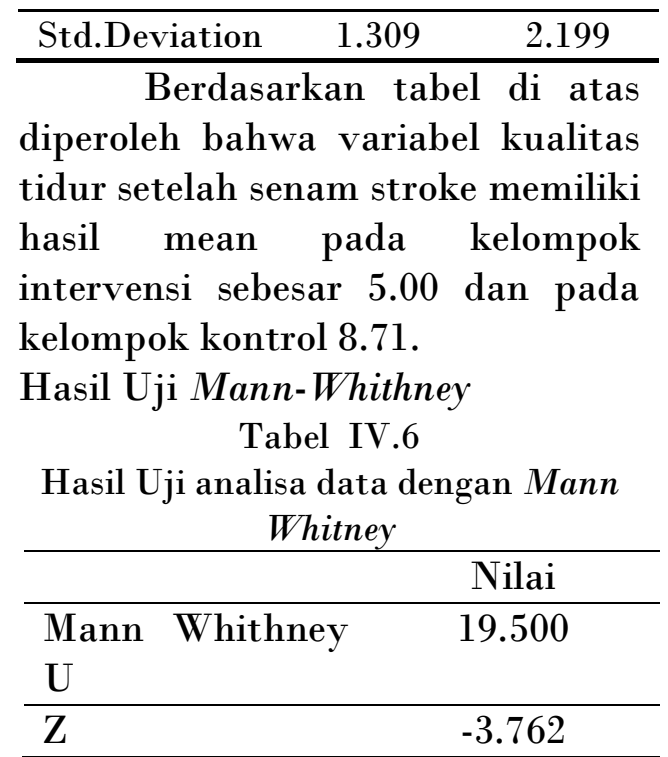

Berdasarkan tabel di atas diperoleh bahwa ada pengaruh pelaksanaan senam stroke terhadap kualitas tidur pada lansia dengan hipertensi di Dusun Siwal. Hal ini dilihat dari nilai p value sebesar 0.00 .

Lansia mengalami perubahan dalam proses kehidupan. Salah satu perubahan yang sering terjadi dalam sistem kardiovaskuler adalah terjadinya peningkatan tekanan darah tinggi. Hal ini ditandai dengan adanya peningkatan sistolik dan diastolik pada tekanan darah. Prevalensi ini meningkat dengan seiring bertambahnya usia seseorang (Hikmaharidha \& Hardian, 2011). Prevalensi terjadinya gagal jantung dan stroke tinggi pada usia lanjut, dan keduanya merupakan akibat dari hipertensi. Pengobatan hipertensi dan pengendalian tekanan darah sangat penting dalam mengurangi morbiditas dan mortalitas pada gangguan kardiovaskuler. Salah satu pencegahan dapat melalui latihan fisik. Olahraga atau latihan fisik pada orang tua yang dilakukan secara rutin akan mengurangi risiko penumpukan lemak pada dinding pembuluh darah yang akhirnya akan menjaga elastisitasnya dan melatih otot jantung dalam berkontraksi (Hikmaharidha \& Hardian, 2011). Hasil penelitian ini menunjukkan bahwa terdapat pengaruh yang signifikan dari pelaksanaan senam stroke yang dilaksanakan seminggu tiga kali yang dilaksanakan oleh lansia di Dusun Siwal pada kelompok intervensi.

$$
\text { Sejalan dengan hasil }
$$
penelitian Setyawan, Yunani \& Kuswati ( 2014), bahwa ada hubungan frekuensi senam lansia terhadap tekanan darah sistolik dan diastolik $(p=0,000)$. Penelitian ini sejalan dengan penelitian yang dilakukan oleh Astari (2012) yang menyimpulkan ada pengaruh yang signifikan antara senam lansia dengan penurunan tekanan darah sistolik dan diastolik pada lansia hipertensi. Jenis olahraga yang efektif menurunkan tekanan darah adalah senam lansia dengan intensitas sedang. Frekuensi latihannya 3-5 kali seminggu dengan lama latihan 20-60 menit sekali latihan ((Rigaud, 2006) dalam Setyawan, Yunani \& Kuswati (2014)).

Latihan fisik yang teratur menyebabkan kerja jantung menjadi lebih efisien. Proses pemompaan darah dalam jumlah yang sama dapat menyebabkan otot jantung menjadi kuat. Penurunan denyut jantung ini menurunkan 
cardiac output, yang pada akhirnya menyebabkan penurunan tekanan darah. Penurunan tekanan darah juga disebabkan oleh menurunnya tahanan perifer karena olahraga lama-kelamaan akan melemaskan pembuluh darah sehingga pembuluh darah mengalami pelebaran dan relaksasi dan juga dapat mengurangi risiko penumpukan lemak pada dinding pembuluh yang akhirnya akan menjaga elastisitasnya (Syatria A, 2006 dalam (Hikmaharidha \& Hardian, 2011)). Sistem saraf simpatis merangsang pembuluh darah sebagai respon rangsang emosi, kelenjar adrenal juga terangsang, mengakibatkan tambahan aktivitas vasokontriksi. Medulla adrenal mensekresi epinefrin, yang menyebabkan vasokontriksi. Korteks adrenal mensekresi kortisol dan steroid lainnya, yang dapat memperkuat respon vasokonstriktor pembuluh darah (Padila, 2013).

Vasokonstriksi yang mengakibatkan penurunan aliran keginjal, menyebabkan pelepasan rennin. Rennin merangsang pembentukan angiotensin I yang kemudian diubah menjadi angiotensin II, suatu vasokonstriktor kuat, yang pada gilirannya merangsang sekresi aldosteron oleh korteks adrenal. Hormon ini menyebabkan retensi natrium dan air oleh tubulus ginjal, menyebabkan peningkatan volume intra vaskuler. Semua faktor ini cendrung mencetuskan keadaan hipertensi (Padila, 2013).
Hasil penelitian pada pasien hipertensi ini menunjukkan kualitas tidur lansia mengalami peningkatan kualitas dilihat dari hasil yang diperoleh. Lansia yang mengikuti senam stroke mengalami peningkatan kualitas tidur. Faktorfaktor yang mempengaruhi kualitas tidur pada lansia antara lain penyakit, stress psikologis, obat, nutrisi, lingkungan, motivasi, gaya hidup dan latihan (senam) (Saryono \& Widianti, 2010). Perubahan kualitas tidur pada lansia disebabkan oleh kemampuan fisik lansia yang semakin menurun. Kemampuan fisik menurun karena kemampuan organ dalam tubuh yang menurun, seperti jantung, paru-paru, dan ginjal. Penurunan kemampuan organ mengakibatkan daya tahan tubuh dan kekebalan tubuh juga terpengaruh yang dapat mempengaruhi proses tidur (Prasadja, 2009).

Wanita memiliki kualitas tidur yang buruk disebabkan karena terjadi penurunan hormon progesteron dan estrogen. Hal ini berpengaruh pada irama sirkadian dan pola tidur secara langsung. Kondisi psikologis, meningkatnya kecemasan, gelisah dan emosi sering tidak terkontrol pada wanita akibat penurunan hormon estrogen yang bisa menyebabkan gangguan tidur(Khasanah \& Hidayati, 2012).

\section{Simpulan}

Gambaran karakteristik responden penelitian adalah 100\% 
lansia termasuk kategori lansia awal dengan jenis kelamin lebih banyak pada wanita sebesar $72,41 \%$, lansia yang memiliki kategori pendidikan dimana tidak bersekolah sebesar $68,97 \%$.

Kualitas tidur pasien sebelum senam stroke pada kelompok kontrol dengan mean 9.29 dan intervensi 9.40

Kualitas tidur pasien sesudah senam stroke pada kelompok kontrol dengan standart deviasi 8.71 dan kelompok intervensi 5.00. Terdapat pengaruh senam stroke terhadap kualitas tidur pada lansia di posyandu Dusun Siwal Selokaton dengan nilai $p$ value $<0.00$.

\section{Daftar Pustaka}

Carpenito, Lynda Juall. 2007.

Diagnosa Keperawatan Aplikasi

Pada Praktek Klinis. Jakarta: EGC.

Hidayat, Syaifurrahman.dkk. (2013). Kecemasan Ibu Hamil dalam Menghadapi proses persalinan. Jurnal kesehatan Wiraraja Medika 2013.

Hikmaharidha \& Hardian. 2011. Pengaruh senam tai chi terhadap tekanan darah wanita berusia 50 tahun ke atas/ Skripsi yang dipublikasikan. Diakses dari

http://eprints.undip.ac.id/33315/

Kasim, R., Draman,N., Kadir, A, B., \& muhamad, R., ( 2016). Knowledge, Attitudes And Practice Of Preconception Care Among Women Attending Maternal Health Clinic In Kelantan. Education in Medicine Journal, 2016; 8 (4); 57-68.
Khasanah \& Hidayati. 2012. Kualitas Tidur Lansia Balai Rehabilitasi Sosial MANDIRI Semarang. Jurnal Nursing Studies, Volume 1, Nomor 1 Tahun 2012, Halaman 189 - 196, Diakses dari : http://ejournalsl.undip.ac.id/index.php.

Kurniasari,Lidia dan Zilawati. (2016). Hubungan Motivasi dan Dukungan Keluarga Ibu hamil dengan pencegahan resiko tinggi Kehamilan di Puskesmas Rawasari tahun 2016. Scientia Journal. Vol 5 No. 02 Desember 2016 STIKes Prima jambi.

Laurika, steppi,dkk. (2016). Hubungan Dukungan Suami Dengan Kesiapan Ibu Hamil Menjelang Proses Persalinan Di RSUD Tugu Rejo Kota Semarang. Stikes Ngudi Waluyo Semarang.

Nursalam. 2011. Konsep dan Penerapan Metodologi Penelitian Ilmu Keperawatan.Jakarta: Salemba Medika.

Oliveira, A. 2010. Sleep Quality of Elders Living in Long-Term Care Institutions.Diakses dari: http://www.scielo.br/pdf/reeusp/ v44n3/en 10.pdf.

Qurniasih, Nila. (2014). Hubungan aktivitas kelas Ibu hamil terhadap kesiapan Ibu Hamil dalam menghadapi persalinan di puskesmas GedongTengen Yogyakarta. Skripsi Program studi D4 kebidanan STIKes 'Aisyiyah Yogyakarta

Sehhatie, F., Najjarzadeh, M., Zamanzadeh, V., \& 
Seyyedrasooli, A., (2014). The Effect of Midwifery continuing care on childbirth outcomes. Iran J Nurs midwifery Res. 2014 may -jun; 19(3):233-237

Stuart, Gail. W. 2006. Buku Saku Keperawatan Jiwa Edisi 5. Jakarta: EGC.

Wahyuni, Dwi. (2005). Pengaruh Kesiapan Belajar, Motivasi Belajar Dan Pengulangan Materi Pelajaran Terhadap Hasil Belajar Mata Pelajaran Ekonomi Pada Siswa Kelas II MA AL ASROR Gunung Pati TA 2004/2005. Skripsi Universitas Negeri Semarang.

Zakky, 2018. Pengertian Pendidikan Menurut Para Ahli dan Secara Umum. Diakses dari :

https://www.zonareferensi.com/p engertian-pendidikan/ tanggal 25 September 2018 